\title{
Policies of International Friendship in Judicial Cooperation in Criminal Matters: The Non-Extradition of Brazilian and Portuguese Nationals to Third States - A Comparison with EU Law
}

\author{
Políticas de Amizade Internacional na Cooperação \\ Judiciária em Matéria Penal - A Não-Extradição de \\ Nacionais Brasileiros e Portugueses para Terceiros \\ Estados (Comparação com o Direito da UE)
}

Miguel João Costa ${ }^{1}$

Tribunal Constitucional Português - Portugal

migueljoao13@hotmail.com

http://orcid.org/0000-0002-2015-6059

\begin{abstract}
This article addresses different implications of nationality in international cooperation in criminal matters, especially in extradition law. Most States, particularly of the civil law tradition, have a longstanding practice not to deliver their own citizens to foreign criminal justice systems. This article begins by reviewing the rationales of the classic nationality exception and contrasts it with the approach of States of the common law tradition, which have no objections of principle to extraditing their own nationals. It then looks into the extradition relations between Brazil and Portugal, following which it provides a brief critical appraisal of the adequacy of the nationality exception in an increasingly globalised world. With these foundational issues settled, the article moves on to questioning what are the effects of interstate affinity upon extradition. It concludes that, in addition to (immediate or direct) effects between the States involved, affinity can also have meaningful (indirect) implications to third States: States which are linked by peculiar (historical, legal, political) bonds sometimes refuse to extradite each other's nationals to
\end{abstract}

1 Ph.D. in Criminal Law, Maastricht University; Advisor at the Portuguese Constitutional Court; Member of the European Criminal Law Academic Network. 
other States. In this regard, the article analyses of the state affairs among the Member States of the European Union following the groundbreaking case law initiated by the Court of Justice in 2016, and compares this recent legal development with the regime that has been in place between Brazil and Portugal since 1971.

KeYwords: Extradition; Nationality Exception; Brazil-Portugal Cooperation; EU Law.

Resumo: O presente artigo analisa as diferentes implicações da nacionalidade sobre a cooperação judiciária internacional em matéria penal, especialmente sobre o direito da extradição. A maioria dos Estados, em particular os da tradição jurídica continental, tem uma longa tradição de não entregar os seus cidadãos para sistemas de justiça criminal estrangeiros. $O$ artigo começa por se debruçar sobre as razões que estão na base desta tradição e faz um contraste com a abordagem seguida pelos Estados da tradição jurídica anglo-americana, que tendem a não levantar objeções à extradição de seus nacionais. Em seguida o artigo atenta nas relações de extradição entre o Brasil e Portugal, fazendo uma breve avaliação crítica da regra da não extradição de nacionais num mundo progressivamente globalizado. Com estas questões essenciais tratadas, o artigo prossegue então para aquela que constitui a sua questão central, que é a de saber que efeitos a existência de laços de afinidade ou proximidade entre Estados pode ter sobre a matéria da extradição. A conclusão proposta é a de que, para além de efeitos (imediatos ou diretos) entre os Estados em causa, essa afinidade se pode também projetar (de modo indireto) sobre Estados terceiros: de facto, por vezes, os Estados que se encontram ligados por peculiares laços históricos, jurídicos e/ou políticos também recusam a extradição para outros Estados dos nacionais um do outro. A este respeito o artigo analisa a situação dos Estados Membros da União Europeia desde a inovadora jurisprudência iniciada pelo Tribunal de Justiça em 2016, comparando este recente desenvolvimento com o regime que já vigora entre o Brasil e Portugal desde 1971.

Palavras-Chave: Extradição; Nacionalidade; Cooperação Brasil-Portugal; Direito da União Europeia.

SUMmarY: 1. Introduction. 1.1. The concept of extradition. 1.2. Classic cooperation and mutual recognition. 1.3. The effects of affinity in interstate cooperation. 2 . The classic nationality exception and the emerging rehabilitation exception. 2.1. A comparative view. 2.1.1. Portugal. 2.1.2. United Kingdom. 2.2. Between Brazil and Portugal. 
2.2.1. The 2005 Extradition Treaty and the 2010 Agreement on Simplified Extradition. 2.2.2. Extradition from Brazil to Portugal. 2.2.3. Extradition from Portugal to Brazil. 2.3. A critical appraisal of the nationality exception. 2.4. Conclusion. 3. The non-extradition of nationals of affiliated States to third States. 3.1. A comparative view. 3.1.1. European Union Law. 3.1.2. The 2000 Treaty of Friendship, Cooperation and Consultation between Brazil and Portugal. 3.2. A comparative appraisal. 4. Conclusion.

\section{INTRODUCTION}

\subsection{The CONCEPT OF EXTRADITION}

Extradition can be defined as the "coercible transfer of a person from one jurisdiction to another at the request of the latter, through a specified procedure and provided that certain conditions are satisfied, for the purpose of carrying out a criminal procedure or enforcing a penalty". ${ }^{2}$

Often regarded as an essentially procedural institute, extradition is in reality an eclectic body of norms which cover procedural as well as substantive matters: the issuing of an extradition request triggers a procedure in the requested State through which at least one judicial entity, and normally also a political one, determine whether the conditions necessary for extradition to be granted are fulfilled. These conditions may constitute simple formalities (such as the requirement that the request indicates the person sought), or truly substantive conditions (such as the requirement that the acts at issue be criminalised in the requested State: the 'dual criminality

2 This definition and other contents provided in this article are further elaborated on in Miguel João Costa, Extradition Law: Reviewing Grounds for Refusal from the Classic Paradigm to Mutual Recognition and Beyond, Leiden: Brill | Nijhoff, forthcoming 2019. For nuanced distinctions between extradition and other cooperation mechanisms, see Pedro Caeiro, "O procedimento de entrega previsto no Estatuto de Roma e a sua incorporação no direito português”, in Vital Moreira / Maria Leonor Assunção / Pedro Caeiro / Ana Luísa Riquito, O Tribunal Penal Internacional e a Ordem Jurídica Portuguesa, Coimbra: Coimbra Editora, 2004, p. 69 f. 
rule'). The latter conditions are usually referred to as 'grounds for refusal' or 'obstacles' to extradition, and they form the substantive dimension of this institute. The nationality of the person targeted by the request is at the core of some of these substantive norms, as discussed later in this article.

\subsection{Classic cooperation and mutual recognition}

As suggested before, within the broader concept of 'extradition', it is necessary to distinguish extradition in a strict sense from surrender two variations of what in essence is one same mechanism. Extradition is the classic version of that mechanism, and it consists of the transfer of individuals between States which are not necessarily linked by ties of political, legal, cultural or historical affinity. The latter is a simpler and more flexible version of that mechanism developed over the past decades among certain groups of States which are connected by ties of that character, on the basis of what has been considered as a new cooperation paradigm: mutual recognition. ${ }^{3}$

The ultimate examples of the concepts of 'surrender' and 'mutual recognition' in criminal matters are the European Arrest Warrant (EAW), developed among the Member States of the EU, ${ }^{4}$ and the Nordic Arrest Warrant (NAW), in force since 2012 between Denmark, Finland, Iceland, Norway and Sweden. Both of these normative instruments operated a significant mitigation of several highly symbolical and practically important traditional grounds for refusal of extradition, notably the dual criminality rule, the political offence exception, and the nationality exception, the focus of this article. ${ }^{5}$

3 Helmut Satzger, "Is mutual recognition a viable general path for cooperation?”, in Pedro Caeiro (org.), Proceedings of the Conference 'European Criminal Law in the Global Context: Values, Principles and Policies' (Abstracts), Coimbra: Instituto Jurídico da Faculdade de Direito da Universidade de Coimbra [IJ], 2018, p. 43 f., conceives mutual recognition as a "flexible" concept "adaptable" to different conditions. In this sense, it is not a specifically concept of EU, but a general one designating enhanced systems of interstate cooperation.

4 Council Framework Decision 2002/584/JHA, of 13 June 2002 (FD-EAW).

5 Regarding the EAW, see e.g. John Vervaele, "European Criminal Law and General Principles of Union Law”, Research Papers in Law 5 (2005), p. 7 f.; 
Another effort to reform classic extradition is the Mercosur Arrest Warrant (MAW), whose signatories are Argentina, Bolivia, Brazil, Ecuador, Paraguay, Peru and Uruguay. ${ }^{6}$ The treaty creating this instrument was concluded in 2010, but has not yet entered into force. ${ }^{7}$ The mitigation of classic grounds for refusal in the MAW is less intensive than in the aforesaid examples, notably in that it envisages the preservation of the traditional political and military offence exceptions, ${ }^{8}$ and allows the executive branch to refuse extradition on account of "special reasons of national sovereignty, security or public order, as well as of other fundamental interests". ${ }^{9}$ Nevertheless, like the EAW, the MAW seeks to streamline contact between States through the designation of central authorities and the use of standardised forms. ${ }^{10}$ It also introduces a partial (if rather moderate) abolition of dual criminality, and it reduces (if also quite moderately) the importance of nationality as ground for refusal of extradition. ${ }^{11}$

Anabela Miranda Rodrigues, O Direito Penal Europeu Emergente, Coimbra: Coimbra Editora, 2008, p. 187 f. On the NAW, see e.g. Annika Suominen, "The Nordic Arrest Warrant finally in force", European Criminal Law Review 4 (2014), p. $41 \mathrm{f}$. Nordic extradition arrangements characterised by very high levels of cooperation have been in place since long before the EAW, and have in fact inspired this creation of EU law: see Gjermund Mathisen, "Nordic Cooperation and the European Arrest Warrant: Intra-Nordic Extradition, the Nordic Arrest Warrant and Beyond", Nordic Journal of International Law 79 (2010), p. $1 \mathrm{f}$., adding that, in elaborating the NAW, Nordic States have in turn drawn inspiration from the EAW; see also Jørn Vestergaard / Silvia Adamo, "Mutual Recognition in Criminal Matters: The Danish Experience", Scandinavian Studies in Law 54 (2009), p. 431 f.; Asbjørn Strandbakken, "Extradition between Nordic countries and the new Nordic Arrest Warrant”, in Nico Keijzer / Elies van Sliedregt (eds.), The European Arrest Warrant in Practice, The Hague: T.M.C. Asser Press, 2009, p. 365 f.

6 On the topic, from a Brazilian standpoint, see Artur de Brito Gueiros Souza, "Extradition in South America. The case of Brazil", ERA Forum 19 (2019), p. $313 \mathrm{f}$.

7 On 22 October 2018 Brazil has promulgated the Law Project no. 104/2018 implementing the MAW in the legal System of Brazil, but the MAW will only become effective 30 days after ratification by at least four countries.

8 See Art. 5 (d) and (e).

9 See Art. 4 (2).

10 See Arts. 2 (4), 6, and 7, as well as Annexes II and III.

11 See Arts. 1, 3 (1), 3 (4), 4 (1) (a), and 5 (a), as well as Annex I. 
It is possible to identify other legal arrangements characterised by above-average levels of cooperation in result of particular ties linking the States involved, such as the Extradition Treaty between Angola, Brazil, Cape Verde, East Timor, Guinea-Bissau, Mozambique, Portugal and São Tomé and Príncipe, concluded at Cidade da Praia in 23 November 2005, ${ }^{12}$ and the Agreement on Simplified Extradition between Argentina, Brazil, Portugal and Spain, concluded at Santiago de Compostela in 3 November de $2010 .{ }^{13}$ While these treaties did not fully eradicate the nationality exception, they did take meaningful steps towards its mitigation.

\subsection{THE EFFECTS OF AFFINITY IN INTERSTATE COOPERATION}

The term 'affinity', as used here, may have different meanings. It may encompass such notions as mutual trust and harmony of legal norms and practices, as is the case within the EU and between the Nordic States. But it may also refer to ties that stem from a common history, language and other factors, even where these do not - at least, not to a comparable degree as in the cases that have just been mentioned - rest upon bonds of normative trust and harmony. ${ }^{14}$

The previous section already denotes that the levels of affinity linking given States has an immediate effect on international cooperation in criminal matters: the higher those levels are, the more intense their cooperation relations will tend to be. Indeed, to a wider or narrower extent, in all of the examples mentioned in the previous section there is an above-average level of affinity between the States involved, and,

12 On this Treaty, see e.g. José de Pina Delgado / Jorge Carlos Fonseca / Liriam Tiujo Delgado (org.), Aspectos Polémicos da Extradição em Cabo Verde e no espaço Lusófono - Nacionalidade, Pena Aplicável, Institutos Afins, Cidade da Praia: Editora do Instituto Superior de Ciências Jurídicas e Sociais, 2009.

13 In Portugal this Treaty has been ratified by Presidential Decree no. 15/2015, but, as far as was possible to determine, it has not yet been ratified by Brazil.

14 In further detail on these concepts and their importance in interstate cooperation, see Miguel João Costa, Extradition Law... op. cit., Chap. 2, § 3.2; in any case, the study ultimately proposes that an improved system of international cooperation could be built upon alternative concepts, namely on that of mutual respect and on that of mutual understanding: see esp. Chaps. 7 and 8 . 
correlatively, in all of them extradition is possible to grant in an aboveaverage number of cases. This is definitely what happens insofar as the topic of this article is concerned: whereas the default principle continues to be the non-extradition of own nationals, in all of the examples mentioned above, as we saw, the States involved at least admit the possibility of reciprocally extraditing their own nationals, and in some cases this has in fact become the rule.

But affinity does not just make it possible for States to adopt increased levels of cooperation between them. It may also, in a mediate or indirect way, lead them into giving further protection to each other's interests in their cooperation relations with third States. Clear illustration of this is provided by the ne bis in idem ground for refusal: if two or more States have pre-existing bonds of affinity which enable them to presume the credibility of the sentences passed by any of them, and if a third State requests to one such State the extradition of a person who has already been tried in any of its 'partner-States' in such terms as to trigger the ne bis in idem protection, then it is only logical that this State refuses the request of the third State. ${ }^{15}$ Another example concerns, again, the nationality of the targeted individual: if two or more States are bound together by strong ties of affinity, and if they generally refuse to extradite their own nationals, then it is understandable that, in certain circumstances, this protection may extend to individuals who are nationals of their partnerStates. This is what occurs with the Nordic States and the Member States of the EU - States which have in place systems of cooperation based on the notion of 'mutual recognition'. And it is also the case of Brazil and Portugal - States which, though not integrated in such a system, have long history of cooperation. These are the two types of interstate relations that will be compared later in this article.

In sum, the existence of ties of affinity between two or more States projects itself in two different (and, in a sense, opposite) directions: it renders extradition easier to grant between those States, and more difficult to grant by any of those States to third States. That these are two effects stemming from one same fundamental cause is quite visible in the Treaty

15 In further detail on this, see Miguel João Costa, Extradition Law... op. cit., esp. Chap. 8, § 3.3.1. 
of Friendship, Cooperation and Consultation, concluded between Brazil and Portugal in 2000, upon 500 years of the arrival of the Portuguese to Brazil: at once, this treaty encourages the further development of extradition relations between those States, in Article 64 (2); on the other hand, it provides in Article 18 that they should not extradite each other's nationals to third States. ${ }^{16}$ The latter aspect is the essential focus of this article, and it will be addressed in section 3. However, it could not be properly addressed without first revisiting the nationality exception itself, which is done in section 2 , immediately below.

\section{The CLASSiC NATIONALITY EXCEPTION AND the EMERgING REHABILITATION EXCEPTION}

\subsection{A comparative View}

This section provides a brief account of how the nationality exception is regulated in the Portuguese legal system, which serves here as an illustration of the continental or civil law States' tradition not to extradite their own nationals, and in the legal system of the United Kingdom (UK), as a representative of the common law tradition, where nationality does not as a matter of principle prevent extradition.

\subsubsection{Portugal}

Article 5 (1) (e) of the Portuguese Penal Code provides that Portugal has jurisdiction over acts committed by Portuguese citizens so long as: they are found in Portuguese territory; the acts are also criminalised in the locus delicti (unless this State does not exercise ius puniendi); and the acts constitute offences for which extradition could in the abstract be granted, but for some reason this was impossible in the concrete case. Most authors explain this basis for jurisdiction as a means to compensate for the non-extradition of

16 See further infra, $\S 3.1 .2$. These rules were already present in a 1971 Treaty, also addressed infra. 
nationals. ${ }^{17}$ However, active nationality, as conceived in the Penal Code, allows Portugal to prosecute acts committed by its nationals abroad even if does not receive any request for the extradition of these individuals, ${ }^{18}$ meaning that this rule of jurisdiction is prior to, and independent from, any extradition law issue. ${ }^{19}$

In turn, Article 32 (1) (b) of the statute which regulates extradition in the absence of a treaty (Law no. 144/99, of 31 August), drawing on Article 33 (3) of the Constitution, lays down the rule of non-extradition of nationals. Since the constitutional amendment of 1997 , this rule is no longer absolute. It is now possible to extradite Portuguese citizens if the following - if "very restrictive" $-{ }^{20}$ conditions are satisfied: (i) reciprocity is secured on the basis of an international treaty; (ii) the acts refer to terrorism or international organised crime; (iii) the requesting State guarantees a due process; and, unless the person explicitly waives this condition, (iv) extradition is requested for prosecution and the requesting State guarantees the return of the person for enforcement in the event

17 See e.g. Jorge de Figueiredo Dias, Direito Penal. Parte Geral. Tomo I: Questões Fundamentais. A Doutrina Geral do Crime, Coimbra: Coimbra Editora, 2004, p. 216; Manuel António Lopes Rocha / Teresa Alves Martins, Cooperação Judiciária Internacional em Matéria Penal: Comentários, Lisboa: Aequitas / Editorial Notícias, 1992, p. 75; Germano Marques da Silva, Direito Penal Português I, Parte Geral: Introdução e Teoria da Lei Penal, Lisboa: Editorial Verbo, 2001, p. 299, $313 \mathrm{f}$.; see also the ruling of the Court of Appeal of Oporto of 14 February 1990, no. 0123625.

18 See Miguel João Costa, Dedere Aut Judicare? A Decisão de Extraditar ou Julgar à luz do Direito Português, Europeu e Internacional, Coimbra: Instituto Jurídico da Faculdade de Direito da Universidade de Coimbra, 2014, p. 63 f.

19 See Pedro Caeiro, Fundamento, Conteúdo e Limites da Jurisdição Penal do Estado. O Caso Português, Coimbra: Wolters Kluwer Portugal | Coimbra Editora, 2010, p. 203 f.; Julian J. E. Schutte, “O Direito Internacional Público e a Competência Extraterritorial em Matéria Penal”, Revista Portuguesa de Ciência Criminal 3 (1993), p. 19, positing that the repression of acts committed by nationals abroad is still required by direct punitive interests of the State. See also Miguel João Costa, Dedere Aut Judicare?... op. cit., p. $53 \mathrm{f}$.

20 Nuno Piçarra, “A proibição constitucional de extraditar nacionais em face da União Europeia”, Revista do Centro de Estudos Judiciários 7 (2007), p. 251. See also Damião da Cunha, "Artigo 33. "”, in Jorge Miranda / Rui Medeiros, Constituição da República Portuguesa Anotada, Vol. I, $2^{\text {nd }}$ ed., Lisboa: Universidade Católica Editora, 2017, p. 544. 
he/she is convicted (Article 32 (2) and (3)). ${ }^{21-22}$ In ruling no. 403/2015, of 27 August 2015, the Constitutional Court stated that this constitutional amendment was a consequence of enhanced imperatives of security and reaction against serious types of criminality which call for "new normative balances between conflicting values". Piçarra claims that the 1997 amendment marked the beginning of the recognition, in Portugal, that refusing extradition of own nationals is not an unchallengeable idea, but one which should be understood "with critical detachment", in a spirit of communion of interests among States and of respect for the primacy of territorial jurisdiction. ${ }^{23}$ Still, extradition of nationals remains quite exceptional.

One possible manner of justifying this nationality exception is to construe it as a consequence of an interest of the Portuguese State in punishing acts committed by its nationals abroad: Portugal would refuse to extradite its own nationals in order to punish their crimes - a reasoning which is symmetrical to that according to which Portugal would punish acts committed by its nationals because it cannot extradite them. Within this line of thought, it is alleged that there is an "umbilical" ${ }^{24}$ relationship between States and their nationals which extends beyond borders, and that this relationship entails a duty of loyalty of the latter towards the former. ${ }^{25}$

21 The last condition is not required by the Constitution; only by the extradition statute.

22 Originally, the sole practical implication of the 1997 constitutional amendment was the possibility to extradite based on the 1996 EU Extradition Convention, since no other international instrument ratified by Portugal, at the time, met those constitutional requirements: see Luís Silva Pereira, "Contributo para uma Interpretação dos Artigos 12 n. ${ }^{\circ} 1$ al. g) e 13. ${ }^{\circ}$ al. c) da Lei n. ${ }^{\circ}$ 65/2003, de 23 de Agosto”, Revista do Centro de Estudos Judiciários 7 (2007), p. 267. Nuno Piçarra, op. cit., p. 236; see also José Vera Jardim, "Por fim, podemos extraditar portugueses! - Explicações de um Ministro”, in António José Avelãs Nunes et al., A Inclusão do Outro, Coimbra: Coimbra Editora, 2002, p. 97.

24 Marc Henzelin, Le principe de l'universalité en droit pénal international: Droit et obligation pour les états de poursuivre et juger selon le principe de l'universalité. Basel: Schulthess, 2001, p. 133.

25 Apparently leaning toward this position, although acknowledging that the ius puniendi of the State of nationality should, in these cases, be subject to "serious limitations", see Eduardo Correia, Direito Criminal (com a colaboração de Figueiredo Dias), Volume I, Coimbra: Almedina, 1963, p. 166. 
Thus, States would be entitled to something of a right of surveillance over their nationals. ${ }^{26}$ This view assumes that active nationality is such a strong jurisdictional basis that States seek as much as possible to exert it. However, this reasoning is also inconsistent with the law currently in force in Portugal: if the main goal indeed were to punish acts committed by nationals abroad, then active nationality would not have been limited to the cases where they are 'found in Portugal' and 'cannot be extradited'.

In this light, the only plausible justification for the Portuguese nationality exception is the intention of the Portuguese State to protect its nationals from foreign punitive systems. This view too acknowledges the existence of an 'umbilical' connection between the State and its nationals, but from that connection it draws, not a right of the State to survey its citizens, but a duty (or at least a prerogative) to protect them. ${ }^{27}$ Only this view can explain why non-extradition of nationals is enshrined as a fundamental individual right in the Constitution, and why it can only be set aside if trust in the foreign legal system is presupposed in the abstract (as is the case within the EU) or verified in the case (after it is established that the requesting State guarantees a due process). It is also the only view capable of explaining why the concept of 'national' for the purposes of the nationality exception is determined by reference to the moment of extraditing, rather than to that when the acts were committed, which is the relevant moment for the purposes of jurisdiction based on active nationality. ${ }^{28}$ Thus, if a person obtains Portuguese nationality after committing a crime, he/she will still benefit from the nationality exception, ${ }^{29}$ and yet Portugal will be unable to prosecute him/her based on active nationality. ${ }^{30}$ In sum, in Portugal, the rationale of the nationality exception is the endeavour of the Portuguese State to protect its citizens

26 A conception which is somewhat characteristic of authoritarian conceptions of State: see Helmut Satzger, International and European Criminal Law, München: Nomos, 2012, p. 20.

27 See Julian J. E. Schutte, “O Direito Internacional Público...”, op. cit., p. 18.

28 See Art. 32 (6) of Law no. 144/99.

29 See e.g. the Ruling of the Court of Appeal of Lisbon of 17 November 2011, no. 759/11.0YRLSB-3.

30 The person may still be prosecuted, but not based on active nationality; rather, based on vicarious jurisdiction (Art. 5 (1) (f) of the Penal Code). 
from the punitive systems of other States. This principle is not absolute anymore, but the exceptions are narrow.

The one great exception to that principle is found, not in classic extradition, but in the EAW system: the execution of EAWs by Portugal concerning its nationals is possible under Article 33 (5) of the Constitution, enacted in 2001. Here, the view that the legal systems of EU partners are deserving of trust is added by another set of arguments: it would be hypocritical to support the furthering of EU integration, EU citizenship and free movement, whilst allowing individuals to rely on their nationality to dodge the criminal justice systems of the partners to that project. ${ }^{31}$ Still, the Portuguese statute implementing the FD-EAW made use of all the room left by the FD to protect own nationals (Law no. 65/2003, of 23 August): according to Article 12 (1) (g) of this statute, Portugal can only execute EAW's issued for prosecution if guarantees are provided that the person will be returned for enforcement; according to Article 13 (1) (b), if the EAW is already requested for enforcement, then Portugal can undertake to enforce the foreign sentence instead of surrendering its national.

However, these norms do not apply to nationals only, but also to other persons who generally receive no specific protection from the Portuguese State against classic extradition, notably residents. This means that these norms do not express anymore a nationality exception in its most traditional sense, or otherwise it would not be possible to surrender an own national for prosecution, but rather a 'rehabilitation exception', ${ }^{32}$ whereby the requested State presumes itself to be the best place for its nationals and residents to be rehabilitated.

In sum, it is fair to say that, in its cooperation with EU partners, Portugal has abolished the nationality exception entirely. ${ }^{33}$ At the same

31 See e.g. Anabela Miranda Rodrigues, "O Mandado de Detenção Europeu - Na Via da Construção de um Sistema Penal Europeu: Um Passo ou um Salto?", Revista Portuguesa de Ciência Criminal 13 (2003), p. 54

32 See also Nuno Piçarra, op. cit., p. 252.

33 See Ricardo Jorge Bragança de Matos, "O princípio do reconhecimento mútuo e o Mandado de Detenção Europeu”, Revista Portuguesa de Ciência Criminal 14 (2004), p. 358; see also the rulings of the Supreme Court of 12 November 2008, no. 08P3709, and of 9 February 2011, no. 1215-10.9YRLSB.S1, mentioning the "abolition" and "disappearance" of this classic rule. 
time, another exception (the rehabilitation exception) emerged which does also profit nationals, but only in part (as it does not protect them from prosecution, just from enforcement), and only incidentally (as it is not rooted in a mistrust of foreign systems, but in an objectively founded belief that the State of nationality and/or residence is the one that offers the best prospects of rehabilitation). ${ }^{34}$

\subsubsection{UNITED KINGDOM}

In contrast with most civil law States, the UK does not take a principled stance not to extradite its own citizens. This is a deeply rooted tradition, ${ }^{35}$ which "has even greater force in the age of the jet aeroplane" ${ }^{36}$ The absence of a nationality exception is perfectly aligned with the absolute subsidiarity assigned by the UK to extraterritorial jurisdiction. In the UK, the principle is that only territorial acts should be prosecuted.

However, the connections of the requested person with the UK (including citizenship) are not completely disregarded: they are taken into account in the context of forum, human rights and humanitarian grounds for refusal. ${ }^{37}$ Some of these grounds for refusal were in fact reportedly

34 See also the ruling of the Supreme Court of 27 April 2006, no. 04P4738, declaring that Article 12 (1) (g) of Law no. 65/2003 is to be construed in the light of the goals of criminal punishment, chiefly of the principle of rehabilitation enshrined in Article 40 (1) of the Penal Code.

See John Basset Moore, A Treatise on Extradition and Interstate Rendition, Boston: Boston Book Company, 1891, p. 157, stating that "refusal to surrender citizens must (...) be regarded as resting upon sentimental considerations and an exaggerated notion of the protection which is due by a state to its subjects": "there appears to be no valid reason why the system of extradition, which is intended to avert a failure of justice should not be extended to citizens or subjects. As long as the citizens of a country are accorded justice abroad, no right of intervention of their government on their behalf accrues and there is no occasion for the assertion of its protective power."

36 House of Lords Select Committee on Extradition Law, "2nd Report of Session 2014-15 - Extradition: UK law and practice", ordered to be printed 25 February 2015 and published 10 March 2015, p. 51.

37 See sections 83A to 83F (especially $83 \mathrm{~A}(3)(\mathrm{g})$ ), 87 (in articulation with Art. 8 ECHR), 91 (idem) and s. 206 of the Extradition Act 2003; on the history of the latter provision, see Scott Baker / David Perry / Anand Doobay, "A Review of the United Kingdom's Extradition Arrangements (Following Written 
enacted in reaction to public protest against the possible extradition of nationals of the UK in some sensitive cases. At any rate, this is still fundamentally different from providing that citizenship, in and of itself, should prevent extradition: on the one hand, these grounds for refusal apply to individuals who are not nationals of the UK; on the other hand, nationality is only one among several factors capable of influencing the decision whether or not to extradite. ${ }^{38}$

\subsection{Between Brazil and Portugal}

Although the tradition in Portuguese-speaking countries is to make use of a nationality exception, and although these countries are not currently integrated in a political, institutional and normative setting barely comparable to that in place for instance in the EU, their bonds of affinity led them into admitting the possibility of reciprocally extraditing their nationals, through the mentioned 2005 Praia Extradition Treaty and 2010 Agreement on Simplified Extradition. As noted before, the main focus of this article lies not so much on the extradition relations between Brazil and Portugal as in their relations with third States insofar as each other's nationals are concerned. Nevertheless, a brief overview must be provided of the state of affairs of the nationality exception between Brazil and Portugal, ${ }^{39}$ so that a complete view emerges of this bilateral relationship. ${ }^{40}$

Ministerial Statement by the Secretary of State for the Home Department of 8 September 2010) - Presented to the Home Secretary on 30 September 2011", 2011, p. 259 f.

38 It should nevertheless be noted that the UK does occasionally subscribe to a nationality exception in the context of extradition treaties concluded with States where the tradition is the non-extradition of nationals, probably in order to maintain a reciprocity nexus in these relations: see Christopher L. Blakesley, "The Law of International Extradition: A Comparative Study", in John Dugard / Christine van den Wyngaert (eds.), International Criminal Law and Procedure; Brookfield: Dartmouth, 1996, p. 180.

39 For a thorough analysis of this specific aspect, see J.J. Gomes Canotilho / Nuno Brandão, "A extradição de Portugal para o Brasil de cidadãos portugueses naturalizados", forthcoming soon in Revista Direito GV.

40 A relationship which, inasmuch as extradition is concerned, goes back as far as to the 1872 Extradition Treaty (and even to the 1855 Convention on Fake Currency, which already contained an extradition provision for that type 
Extradition cases between Brazil and Portugal represent a significant fraction of the overall number of cases processed by these countries. Looking from the perspective of Brazil, and relying on the empirical analysis provided by Diniz and Pereira, between 2000 and 2010, from more than 270 rulings delivered by the Brazilian Federal Supreme Court on extradition matters, $62 \%$ resulted from requests issued by EU Member States, and 19\% of these from requests issued by Portugal. On the other hand, of all the rulings (resulting from requests issued by any State) in which that Court found extradition to be inadmissible, in 5\% of them the fact that the person was a Brazilian national barred extradition. ${ }^{41}$

\subsubsection{The 2005 Extradition TREATY AND tHe 2010 AgreEMENT ON SIMPLIFIED EXTRADITION}

The 2005 Extradition Treaty was concluded in Praia, Cape Verde, and replaced the bilateral arrangements that were in place between the same States, including the one that had been concluded between Brazil and Portugal in Brasilia on 7 May 1991, whose Article III (1) (a) prohibited extradition of nationals. ${ }^{42}$ The fact that the Praia Treaty provides (in Article 4 (a)) for an option to extradite nationals is an immediate and strong signal that the States Parties acknowledge that they are linked by

of offence). The 1872 Treaty is thoroughly analysed (its political and diplomatic contexts included), in Maria Cecília de Sousa Cameira, "A Arte do Compromisso: Tratado de extradição de criminosos entre Portugal e o Brasil (10.06.1872)", in Zília Osório de Castro et al. (eds.), Tratados do Atlântico Sul: Portugal-Brasil, 1825-2000, Ministério dos Negócios Estrangeiros, 2006, p. 99. $\mathrm{f}$. It should be acknowledged that the negotiation of the treaty is reported to have been prolonged and not deprived of animosity between the parties: see ibid., esp. p. $129 \mathrm{f}$.

41 Irene Bogado Diniz / Marcos Vinícius Torres Pereira, "Uma Análise da Jurisprudência do Supremo Tribunal Federal sobre Extradição: O Brasil Não É o Paraíso para os Criminosos Estrangeiros”, Cosmopolitan Law Journal 2 (2014), p. $186 \mathrm{f}$.

42 The 2005 Praia Treaty was approved in Portugal by Parliament Resolution no. 49/2008 and ratified by Presidential Decree no. 67/2008. As for Brazil, the Treaty entered into force at the external level on 1 June 2009, after approval by the National Congress through Legislative Decree no. 45, of 30 March 2009, and it was promulgated by Decree no. 7.935, of 19 February 2013. 
special bonds, because the principle in their legal systems, in line with the civil law tradition, is non-extradition of nationals. One should not play down this signal of increased willingness to cooperate.

However, as noted, this constitutes merely an option, which may or may not be given effective application by the States Parties. In the Praia Treaty, they did not go so far as to hold themselves obliged to extraditing their nationals. This approach is less cooperation friendly not only than that adopted in the EAW system (to which Portugal is a Party), but also than that adopted in the MAW (to which Brazil is a Party), where extradition of nationals can only be refused based on a constitutional provision in force in the requested State, or if the requesting State has one such provision in force and in consequence cannot guarantee reciprocity to the now requested State in future cases. In contrast, the Praia Treaty enables the refusal of extradition of nationals based on a case-by-case basis which need not be grounded on constitutional law. Therefore, the refusal by a State Party to extradite a national does not, in any instance, breach an obligation stemming from the Praia Treaty, although the fact that this Treaty admits extradition of nationals can already trigger some diplomatic reaction if a State does choose not to do so (and in part this is why the approach of the Praia Treaty, albeit more moderate than other approaches, should not be underestimated).

In turn, the 2010 Agreement on Simplified Extradition reads closer to the MAW, by establishing in its Article 4 (1) that the nationality of the person cannot be invoked to refuse extradition, unless otherwise provided for by a constitutional norm. ${ }^{43}$ It therefore takes the admissibility of extradition of nationals one step further than the Praia Treaty. It must be noted that, with the coming into force of the 2010 Agreement, the provisions of the 2005 Praia Treaty will only apply between Brazil and Portugal inasmuch as they regulate aspects which are not covered by the former. ${ }^{44}$ And since the 2010 Agreement regulates the nationality issue

43 Moreover, Article 4 (2) provides that the status of national is to be determined by the requested State, and should be met at the time of the acts and endure in the moment of taking the decision on the extradition request, so long as it was not obtained with the fraudulent purpose of preventing extradition.

${ }_{44}$ See 1 (2) of the 2010 Agreement. 
in detail, these will then be the norms of reference between Portugal and Brazil on the extradition of nationals.

In any event, whether under the 2005 or the 2010 legal instrument, extradition of nationals will be impossible if a constitutional rule is in place which so prevents. And this is exactly what currently happens: stringent constitutional rules are in place in Brazil and Portugal which render extradition of nationals between those countries possible in only a very limited number of cases.

\subsubsection{Extradition from Brazil to Portugal}

Regarding Brazil, extradition of nationals is prohibited in very broad terms by Article 5 (LI) of the Constitution, ${ }^{45}$ which is included in the catalogue of fundamental individual rights. According to this provision, Brazil cannot, in any circumstances, extradite born citizens; as for naturalised citizens, they can only be extradited for common offences committed before they have obtained Brazilian citizenship, or in cases of proven involvement in drug trafficking. ${ }^{46}$ This practically prevents Brazil from giving any actual effect to the option to extradite nationals opened by the Praia Treaty.

45 This provision is concretised at the ordinary level in Article 77 (I) of Law no. 6.815/80 (generally referred to as 'Estatuto do Estrangeiro'). A different question is that as to whether the Constitution of Brazil prevents the surrender of Brazilian nationals to the International Criminal Court: on this issue, and leaning towards the view that surrender is possible, see João Grandino Rodas, "Entrega de nacionais ao Tribunal Penal Internacional", Revista do Centro de Estudos Judiciários 4 (2000), p. 31 f.; Leila Poconé Dantas, "Entrega de Nacionais ao Tribunal Penal Internacional versus Vedação Constitucional de Extradição", Revista da Escola Superior da Magistratura de Sergipe 10 (2007), p. 35 f.; and Artur de Brito Gueiros Souza, op. cit., p. 330 f., stating that this has become the dominant view in Brazilian legal literature, supported on an understanding according to which classic extradition and surrender to the ICC "are different in content and form", as the former abides by the traditional horizontal model of cooperation, whereas the latter is vertical in character.

46 According to Artur de Brito Gueiros Souza, op. cit., p. 326: "This constitutional innovation has to do with the (...) phenomenon of international drug trafficking and its impact on South American countries". 
Moreover, the hypothesis of involvement in drug trafficking requires a specific procedure which must be 'established by law', ${ }^{47}$ and reportedly no law has established such a procedure thus far. ${ }^{48}$ Consequently, extradition of naturalised citizens based on that hypothesis is possible only if the request is issued together with evidence of such an involvement, including a final sentence convicting the person for an offence of that character. ${ }^{49}$

Furthermore, according to Article 60 (4) (IV) of the Constitution, the catalogue of fundamental individual rights (where, as noted, the nationality exception is inserted) cannot be abolished through a constitutional amendment..$^{50}$ While this norm might still admit a reform of the prohibition to extradite nationals as currently contained in Article 5 (LI), in such a way as to narrow its scope, the fact is that thus far this prohibition has never been amended, ${ }^{51}$ which is not particularly

47 See Pedro Lenza, Direito Constitucional Esquematizado, $20^{\text {th }}$ ed., São Paulo: Saraiva, 2016, p. 1331, supported on case law of the Federal Supreme Court; and Luiz Carlos Ormay Júnior / Rejane Alves de Arruda, "O Processo de Extradição e seus Limites no Brasil: Apontamentos de Acordo com o Entendimento do Supremo Tribunal Federal", Revista Thesis Juris 7 (2018), p. 191, noting that such a procedure presupposes a deviation from the principle according to which the decision on extradition should not involve an assessment of the merits of the case, which is the approach followed in Brazil, in the image of most civil law States and in contrast with States form the common law tradition, where some evidence of criminal liability is usually required (see Scott Baker / David Perry / Anand Doobay, op. cit., p. 39 f.).

See Fabiane Segabinazi, "Uma análise da extradição no Direito brasileiro", Revista da Faculdade de Direito da Universidade Federal do Rio Grande do Sul 24 (2004), p. 161; also Artur de Brito Gueiros Souza, op. cit., p. 325 f., also analysing the meaning of the expression 'common offences' as intended by this provision.

49 See Fabiane Segabinazi, op. cit., p. 161, stating that this was the "solution" to this quandary found by the Supreme Federal Court.

50 Article 5 (LI) therefore constitutes what in Brazilian constitutional law is commonly referred to as a 'claúsula pétrea': see e.g. Valerio de Oliveira Mazzuoli, “Algumas Questões sobre a Extradição no Direito Brasileiro”, Cadernos da Escola de Direito e Relações Internacionais 14 (2011), p. 165.

51 In contrast with the nationality exception contained in Article 33 of the Portuguese Constitution. 
auspicious for increased cooperation by Brazil concerning offences committed by its nationals. ${ }^{52}$

Nevertheless, the current Brazilian Constitution of 1988 already represented a step towards greater availability by Brazil to extraditing its nationals, when compared to the previous Constitutions going back to that of 1934, all of which prohibited, with no exception, extradition of nationals..$^{53}$ The adequacy of the nationality exception has also been called into question by Brazilian literature, for instance by, Del'Olmo, who argues that "the moment has arrived for the legislator to consider inscribing Brazil amongst the set of States that have ceased to protect offenders for the sheer reason that they are their citizens". ${ }^{54}$ Finally, it should be noted that a person may be extradited if he/she, though once a Brazilian citizen (even if a born citizen), has later lost this status (for instance, in result of voluntarily obtaining the nationality of another State which does not recognise Brazilian born citizenship). ${ }^{55}$

52 Particularly if we note that Brazil has had in place for decades extradition treaties which would enable it to extradite its nationals, such as the 1961 Treaty with the USA (see its Article 7).

53 See Guilherme Aresi Madruga Lopes, Extradição Passiva e Nacionalidade Investigação sobre a viabilidade jurídica da extradição de pessoa que perdeu a nacionalidade brasileira originária, Porto Alegre: Universidade Federal do Rio Grande do Sul, 2018 (Bachelor Thesis), p. 51, with more references. Before the 1934 Constitution, extradition of nationals was admitted, in reciprocal conditions, by Law no. 2.416 of 1911: see Maurício Augusto Gomes, "Aspectos da extradição no Direito brasileiro”, Justitia 52 (1990), p. 49.

54 Florisbal de Souza Del'Olmo, “A Extradição na Contemporaneidade: Breves Reflexões”, Cadernos do Programa de Pós-Graduação da Universidade Federal do Rio Grande do Sul 4 (2005), p. 83 f. (translated by myself), drawing attention to the fact that Brazil was the number one country in the world in cybercrime levels in 2002. According to Maurício Augusto Gomes, op. cit., p. 48, "most authors" in Brazil now contest the strict prohibition on the extradition of nationals contained in the Constitution.

55 See Florisbal de Souza Del’Olmo, "Extradição de Nacional no Direito Brasileiro: O Pioneirismo do Caso Cláudia Hoerig”, Revista da Faculdade de Direito Universidade Federal de Minas Gerais 69 (2016), p. 782; see Article 12 (4) of the Brazilian Constitution and Article 23 of Law no. 818/1949. In any event, the case of Cláudia Hoerig is reportedly the first and, so far, only case in which this has occurred. 


\subsubsection{Extradition from Portugal to Brazil}

Regarding Portugal, as stated before, since the 1997 constitutional amendment it can extradite its nationals in a given set of cases which is significantly wider than that in which Brazil can extradite its nationals. First, because born citizens can be extradited. Second, because naturalised citizens can be extradited even if the offence at issue was committed after they became Portuguese citizens. Third, because, although extradition is limited to given types of criminality, these include some of the most serious ones, namely terrorism and organised international criminality, rather than being limited to the very specific case of drug trafficking. Fourth, because the actual involvement of the requested person in offences falling within those types of criminality is not required, but rather the traditional no-evidence rule applies in the same terms as for any other aspect of the extradition procedure. Still, these conditions mean that extradition of nationals by Portugal remains fairly exceptional (EU context aside) .

Moreover, one of those conditions is that reciprocity be established through an international convention. But while such a convention does exist with Brazil, it seems clear that Portugal will be unable to extradite its nationals to Brazil in cases where, by definition, Brazil could not reciprocate. And since Brazil can barely ever extradite its nationals, Portugal will barely ever be able to extradite its nationals to Brazil. ${ }^{56}$

Furthermore, it is questionable whether Portugal can even extradite a national to Brazil when this person is a naturalised Portuguese national and the offence was committed before nationality was obtained: although Brazil can extradite its nationals in these cases (which would allow for the fulfilment of the reciprocity requirement of the Portuguese Constitution), extraditing one such individual to Brazil would likely be untenable in the light of the equality principle enshrined in the Portuguese Constitution (Article 13), since no differentiation appears to be accepted by this Constitution between different modalities of Portuguese citizenship: Article 33 (3), on the (non-)extradition of nationals, does

56 On the prominent case of Raul Schmidt, before the Portuguese courts (process no. 483/16.7YRLSB), see the rulings of the Court of Appeal of Lisbon of 7 December 2016, and of the Supreme Court, of 7 September 2017. On the whole topic, see again J.J. Gomes Canotilho / Nuno Brandão, op. cit. 
not make any such differentiation, nor does Article 4, the general norm on Portuguese nationality. ${ }^{57}$ The latter norm provides that Portuguese citizens are "any individuals who are considered as such by law or by an international convention", and the law considers Portuguese citizens not only individuals who are Portuguese by birth, but also individuals who, in different ways and by satisfying different sets of conditions, have later obtained Portuguese nationality. ${ }^{58}$

The conclusion is that, despite the steps taken in the 2005 Praia Convention and in the 2010 Agreement on Simplified Extradition towards enabling extradition of nationals - which, as stated repeatedly, does constitute a meaningful signal of interstate affinity -, at present this possibility remains practically precluded in the relations between Brazil and Portugal, due to their Constitutions, particularly to that of Brazil.

\subsection{A critical appraisal of the nationality exception}

There is no rule of general international law prohibiting a State from extraditing its own nationals to other States, and there most certainly is no human right not to be extradited by one's own State. ${ }^{59}$ Nor is there, a fortiori, one such rule prohibiting a State from extraditing a person who is a national of another State to which it is bound by ties of affinity. ${ }^{60}$ And while a rehabilitation exception can be justified on criminological grounds, there is no solid reason to claim that nationality

57 In Brazil, such a differentiation is generally not admitted either, unless it is effected by the Constitution itself (Article $12(2)$ ), which is precisely the case of Article 5 (LI), on extradition: see Pedro Lenza, op. cit., p. 1329.

58 See Law no. 37/81, of 3 October (the 'Statute on Portuguese Nationality'), and Decree-Law no. 237-A/2006, of 14 de December (the 'Regulation on Portuguese Nationality').

59 See e.g. Bert Swart, "Refusal of Extradition and the United Nations Model Treaty on Extradition”, Netherlands Yearbook of International Law 23 (1992), p. $189,191 \mathrm{f}$.

60 One such prohibition is in certain circumstances now imposed by EU law upon EU Member States, but this prohibition is not grounded on human rights: rather, on certain principles and freedoms specific to that normative building: see infra, 3.2 . 
should continue to produce such hindering effects upon interstate cooperation as it still does. ${ }^{61}$

No doubt, at its inception, the nationality exception had a clear dimension of individual protection. For instance, the Bulle Brabantine of 1355 mirrored a "general feeling that the citizens of one State or region would be always at a grave disadvantage in securing justice from the courts of another". ${ }^{62}$ This line of reasoning held strength way into the in the late modern era, when the nationality exception was for the first time enshrined in a written legal norm (in the very opening provision of the 1834 Extradition Treaty between Belgium and France).

However, the development of a human rights system following WWII rendered this 'protective' facet of the nationality exception superfluous and even discriminatory, in the sense that, from a human rights standpoint, potentially unfair or discriminatory persecutions should always carry the refusal of extradition, regardless of the nationality of the individual at stake. ${ }^{63}$ This is the concept underlying such human rights and other individual-oriented extradition rules as the non-refoulement clause, ${ }^{64}$ the rehabilitation exception, ${ }^{65}$ and due process grounds for refusal. ${ }^{66}$ The problem with the nationality exception is that it presumes that nationals will be discriminated against, or subjected to an undue process, or forced

${ }^{61}$ See Miguel João Costa, Extradition Law... op. cit., Chap. 8, §§ 3.4.1 and 4.3.1.

Ivan Anthony Shearer, "Non-Extradition of Nationals - A Review and Proposal”, Adelaide Law Review 2 (1966), p. 274 f.

63 As construed by Margaret R. Somers, Genealogies of Citizenship: Markets, Statelessness, and the Right to Have Rights, Cambridge: University Press, 2008, p. 161 f., drawing on Arendt's momentous work on citizenship, whereas "[m]odern ideas of rights derive from natural law and are attached to people not as citizens of any particular political entity but as abstract Men with natural rights", nationality "is available only to those with the privilege, not the right, of membership in a specific political body existing prior to and independent of any particular human beings": "Looking from the outside in, citizenship is discriminatory and exclusive; but once inside, it is a force for equality and inclusion". See Article 3 (b) of the UN Model Treaty on Extradition.

65 See supra, $\S 2.1 .1$. Extradition. 
to serve a sentence in a place which is detrimental to their rehabilitation. This may be true in some cases, but the point is that: on the one hand, as noted, these concerns should apply not only to nationals, but to any person; on the other hand, they need not be presumed to occur, but rather they should be appraised on a case-by-case basis, with extradition being refused only where they do effectively occur.

It is also interesting to observe the silence of most extradition arrangements on the hypothesis of multiple nationality, in which the person is a national not only of the requested State, but also of the requesting State. ${ }^{67}$ By refusing to extradite even in these cases, a State will be implying that the bond of nationality in the name of which they refuse to cooperate with all other States is not only a privilege, but also a privilege that is only consequential when conferred by itself, in what arguably constitutes an epitome of ethnocentricity. ${ }^{68}$

It is true, as we saw above, that the States which tend not to extradite their own nationals generally reserve themselves the prerogative to prosecute the crimes they commit abroad. In this sense, this approach is still theoretically acceptable in the light of the (enduring) model of ubiquitous criminal justice of the Enlightenment, in that it can prevent those crimes from staying unpunished. However, even these States agree that criminal justice is fundamentally territorial, ${ }^{69}$ which is why their primary basis of jurisdiction is not active nationality, but territoriality. As things stand, it seems clear that the States which refuse to extradite their nationals for crimes committed in other States do not do so because they believe they have strong reasons to prosecute them, but in spite of the fact that they admit that those other States have stronger reasons to do so.

67 This situation is quite relevant, in practice, in the relations between the States in focus here, since their nationality is generally much easier to be obtained by citizens of other Portuguese-speaking States than by other individuals (see e.g., from the perspective of Brazil, Article 12 (II) (a) of its Constitution).

68 And yet, neither for Brazil nor for Portugal does it make any difference that the person is a national of the requesting State too, unless, in the case of Brazil, this carries the loss of Brazilian citizenship (see supra, § 2.2.2).

69 See Pedro Caeiro, Fundamento... op. cit., p. $321 \mathrm{f}$. 


\subsection{CONCLUSION}

In light of this critical analysis, the abolition of the nationality exception in the EAW and its mitigation in the 2005 Praia Extradition Treaty and in the 2010 Agreement on Simplified Extradition constitute welcome and even natural developments.

Insofar as specifically concerns Brazil-Portugal relations, extradition of nationals is currently hindered by their national rules on extradition, in particular by the Brazilian Constitution. However, the issue now rests fully with their national legislators, because at the international level, with the Praia Treaty, the bases are already laid down for cooperation between those countries to intensify, which is justified by the ties of affinity that bind them together.

In turn, as mentioned at the opening of this article, this very affinity produces other effects on international cooperation, namely the refusal of extradition of each other's nationals to third States. These (indirect) effects reinforce even further the bonds between those countries, but they also encumber their extradition relations with the wider world. This is the aspect analysed in the following, core section of this article.

\section{The non-extradition of nationals of affiliated States to THIRD STATES}

\subsection{A comparative VieW}

As noted earlier, insofar as concerns the nationality of the person, the existence of ties of affinity between certain States projects itself in two different and somewhat opposite directions: it renders extradition easier between those States, but more difficult from any of them to third States. The latter aspect will now be addressed: first by reference to EU law as 'revealed' by the ECJ in its ruling in Petruhhin (2016); then by reference to the arrangements that Brazil and Portugal have had in place since 1971, presently condensed in the 2000 Treaty of Friendship, Cooperation and Consultation. 


\subsubsection{EUROPEAN UNION LAW}

Extradition from Member States to third States became a vivid topic of EU law as three cases reached the Court of Justice (ECJ) for preliminary rulings: ${ }^{70}$ the first is Petruhhin (C-182/15), ${ }^{71}$ involving an Estonian requested by Russia on drug-related charges; the second is Schotthöfer \& Steiner (C-473/15), ${ }^{72}$ involving an Austrian tried in absentia in the United Arab Emirates on charges of murder and manslaughter, who feared being extradited if he were to travel to another Member State; the third was Pisciotti (C-191/16), ${ }^{73}$ in which an Italian was extradited on cartel charges from Germany to the United States of America, where he was sentenced to imprisonment for two years after pleading guilty. Already after the ECJ had delivered its ruling on Petruhhin, on 6 September 2016, another case was lodged and ruled on by the Court: Raugevicius (C-247/17). ${ }^{74}$

In its ground-breaking ruling in Petruhhin, the ECJ held that EU primary law might prohibit a Member State from extraditing a citizen of a fellow Member State to a third State. In this manner, the ECJ devised what may be called a 'EU citizenship exception': an obstacle to the extradition of EU citizens from the EU to possibly any State. This ruling was grounded on the freedom of movement enshrined in Article 21 of the Treaty on the Functioning of the EU (TFEU), and on the principle of equal treatment (or prohibition of discrimination) of EU citizens enshrined in Article 18 TFEU. These are two key provisions

70 In further detail on this innovative case law, see Miguel João Costa, "The Emerging EU Extradition Law: Petruhhin and Beyond”, New Journal of European Criminal Law 8 (2017), p. 192 f.; André Klip, "Europeans First!: Petruhhin, an Unexpected Revolution in Extradition Law", European Journal of Crime, Criminal Law and Criminal Justice 25 (2017), p. 195 f.

71 See Opinion of Advocate General (AG) Bot of 10 May 2016, and ECJ Judgment of 6 September 2016. This ruling is also noteworthy for asserting the applicability of EU human rights in extradition proceedings to third States, but this aspect was relatively foreseeable in the light of the CFREU, notably of its Article 19 (2).

72 ECJ Order of 6 September 2017.

73 ECJ Judgment of 10 April 2018.

74 ECJ Judgment of 13 November 2018. 
in the normative edifice of the EU, and their articulation is at the origin of several momentous developments of EU law. ${ }^{75}$

Regarding freedom of movement, the view is that the citizens of a Member State who are sought for extradition by a third State will feel dissuaded from moving into the territory of other Member States if this means that they will cease to be protected by the nationality exception from which they benefit when they are located in their own Member State. This also means that the EU citizenship exception will only operate if a nationality exception would be applicable in the Member State of origin, because evidently a person cannot feel deterred from moving to a Member State because of the fact that this Member State does not offer a protection which is not accorded by his/her Member State either. ${ }^{76}$

Regarding equal treatment, it is clear that refusing extradition of own nationals but not of other EU citizens involves a differentiation based on nationality. However, such a differentiation will only be illegitimate, thereby amounting to actual discrimination, if the nationals and the other EU citizens are in a comparable situation. And according to the ECJ they will generally be in a comparable situation, because the reasons why some Member States do not extradite their own nationals to third States (notably, in order to protect them from potentially disadvantageous criminal proceedings) extend to the nationals of their fellow Member States. There is, however, one factor which may justify differentiation: the 'impunity issue'. Avoiding impunity is a goal that lies at the very core of the institute of extradition. In the light of this goal, the situation of nationals and other EU citizens will only be comparable if, upon refusing extradition, the requested Member State can prosecute the latter (for it can generally prosecute the former, based on active

75 See André Klip, European Criminal Law. An Integrative Approach, $3^{\text {rd }}$ ed., Cambridge: Intersentia, 2016, p. 530 f.

76 See also Markus Röhrig, "Nowhere to Hide? Extradition in Antitrust Cases from a European Perspective", Journal of European Competition Law \& Practice 6 (2015), p. 173. One might also argue that it is unfounded to apply a protection derived from nationality when the Member State conferring this status does not itself accord such protection, but such an argument lacks normative grounding, because, in these cases, it is the legal system of the host Member State (not that of the Member State of nationality) the one whose conformity with EU law is in question. 
nationality), or if the Member State of which the person is a national issues a EAW with a view to prosecuting him/her. Thus, this approach constitutes a concretisation of the old principle aut dedere aut judicare: under certain circumstances, EU primary law does now impose the non-extradition of EU citizens, but only insofar as that does not cause a situation of impunity. In this sense, and even though it may require Member States to breach international obligations they had subscribed to by concluding extradition treaties with third States, it constitutes a sensible approach, in that the punitive claims of third States are not completely disregarded.

At this point, there are still some doubts as to the exact manner how the EU citizenship exception is to function. For instance: (i) whether the requested Member State and/or the Member State of nationality must prosecute the EU citizen in order to avoid his/her extradition to the third State, or rather they have a mere option to do so; and (ii) whether the EU citizenship exception applies in the very same terms when there is an applicable international agreement concluded by the EU and the third State in question, such as the 2003 EU-USA Extradition Agreement. The rulings delivered by the ECJ subsequently to Petruhhin, notably the Pisciotti ruling, cleared out some of the doubts, but in regard of some issues they only dimmed the cloud even further. In any case, it is safe to affirm that, since Petruhhin, EU law prohibits the extradition of EU citizens in certain circumstances, which marks a momentous development of EU Law.

Still, such a development should not in my view be regarded as the birth of an entirely new obstacle to extradition, because its rationale is not autonomous, but rather it is drawn from a pre-existing obstacle: the classic nationality exception. Thus, the most accurate way to qualify the new-born EU citizenship exception would be as a 'derivation or extrapolation of the classic nationality exception into a EU scale'. It is worth emphasising that the ECJ did not in any moment imply that Member States should refuse extradition of their own nationals to third States, but rather, and quite simply, that, if they do so, then they will have to offer identical treatment to other EU citizens.

For this very reason, it would also be inadequate to conceive this development of EU Law as a signal of a fully-fledged citizenship 
status of the EU. ${ }^{77}$ It is the citizenship status conferred by the Member States that gives rise to the nationality exception, and it is the nationality exception that in turn gives rise to the EU citizenship exception: when in contact with the nationality exception found at the Member State level, certain elements of EU Law (namely free movement and equal treatment), prompt - almost as if by organic response - a EU citizenship exception. These elements of EU law are necessary for generating the EU citizenship exception, but this exception only emerges to the extent that such elements contact with the nationality exception found at national level. This is why a EU citizenship exception will not apply if the Member State of origin does not apply a nationality exception (as in this case free movement is not affected), or the Member State to which extradition is requested does not apply a nationality exception (as in this case equal treatment is not affected).

None of this intends to deny the high symbolism of this EU Law development. The nationality exception remains one of the most iconic protections conferred by many States to their nationals, and now it has been given regional breadth. Still, the fact is that the new EU citizenship alone does not generate such a protection, meaning that Member States, if they so wished, could neutralise it completely: they would 'only' have to abandon their old nationality exception.

\subsubsection{The 2000 Treaty of Friendship, Cooperation and Consultation between Brazil and Portugal}

International arrangements between Brazil and Portugal symbolising and giving depth and actuality to their common history have existed practically since the moment of independence of Brazil,

77 With this view, do however see Christian Ritz / Bernardo Vasconcelos, "Extradition discrimination? Pisciotti's legal battle continues as Regional Court of Berlin refers questions of fundamental EU law principles to the CJEU", European Competition Law Review 37 (2016), p. 281, referring to another "milestone in the path to complete European Citizenship". On the history of EU citizenship prior to this development, see Thérèse Blanchet, "From Workers to Citizens - The Evolution of European Citizenship", New Journal of European Criminal Law 7 (2016), p. 142 f. 
more specifically since the 1825 Treaty of Peace and Alliance signed in Rio de Janeiro, where the unilateral proclamation of independence by Brazil in 1822 was recognised by Portugal. ${ }^{78}$ This Treaty was followed inter alia by a 1953 Treaty of Friendship and Consultation, ${ }^{79}$ and in 1971 those two States concluded in Brasilia the Convention on Equality of Rights and Duties, Articles 8 and 9 of which established that "Portuguese and Brazilian nationals covered by the equality status are subject to the criminal law of the State where they reside, in the same conditions as its nationals", and they "are not liable to extradition, save where requested by State of which they are nationals". In 2000, this Treaty was replaced by a new Treaty of Friendship, Cooperation and Consultation, signed in Porto Seguro on 22 April. ${ }^{80}$ Article 18 of this Treaty practically replicates the provisions of the 1971 Treaty concerning jurisdiction and extradition.

The Constitutions of both Brazil and Portugal in force at that moment already provided for a principle of equality between Brazilian and Portuguese nationals, and such a principle is also provided for in the Constitutions currently in force ${ }^{81}$ However, whereas in the case of Brazil the extradition of Portuguese citizens to third States would be directly limited by the Constitution to the (very narrow set of) cases in which Brazilian naturalised citizens can be extradited,${ }^{82}$ in Portugal

78 See Zília Osório de Castro, “A 'Varanda da Europa' e o 'Cais do Lado de Lá' Tratado de paz e aliança entre D. João VI e D. Pedro (29-08-1825)”, in Zília Osório de Castro et. al., op. cit., p. $23 \mathrm{f}$.

79 See Fernando Martins / Pedro Leite de Faria, "Um Primeiro Passo no Bom Caminho O Tratado de Amizade e Consulta (16.11.1953)”, in Zília Osório de Castro et. al., op. cit., p. $251 \mathrm{f}$.

80 On this Treaty, see Cristina Montalvão Sarmento, "Tratado do Milénio: 500 Anos para Redescobrir a História (22.04.2000)”, in Zília Osório de Castro et. al., op. cit., p. 289. f. The Treaty was promulgated in Brazil by Presidential Decree no. 3.927, of 15 September 2001. In Portugal it was ratified by Presidential Decree no. 79, of 14 November 2000, and its application was regulated in further detail through Decree-Law no. 154/2003.

81 See - albeit with nuances which cannot be explored further in this text Article 12 ( $\$ 1$ ) of the Constitution of Brazil and Article 15 (3) of the Constitution of Portugal. The latter Constitution further affirms, in Article 4, that "Portugal shall maintain privileged bonds of friendship and cooperation with Portuguese-speaking countries".

82 See e.g. Artur de Brito Gueiros Souza, op. cit., p. 329. 
the case seems to be slightly different, in that the Constitution requires a "law" to confer one such right upon Brazilian nationals, and this has only occurred with the ratification of the 1971 Treaty (and later with the ratification and regulation of the 2000 Treaty). On the other hand, the Brazilian Constitution requires that reciprocity conditions be met, meaning that such a protection of Portuguese nationals would only apply if Portugal offered a similar treatment to Brazilians. ${ }^{83}$ Thus, were it not for those treaties and their incorporation into the legal orders of Brazil and Portugal, there would arguably be no effective limitations whatsoever on the extradition of each other's nationals to third States.

These limitations on the extradition of Brazilian and Portuguese nationals to third States are not mere 'law in the books', as they have been applied in actual practice. Thus, for instance, on 2 September 1998, the Brazilian Federal Supreme Court - still ruling under the 1971 Treaty (more specifically under Presidential Decree no. 70.391/72, through which Brazil promulgated that Treaty) - refused the extradition of a Portuguese national to Italy and ordered her release from preventative custody, in which she had been placed on account of the extradition request. ${ }^{84}$

It is important to observe that both the Brazilian and the Portuguese Constitutions require, in order for the equality status to be triggered, that the individuals in question be their permanent residents, which presupposes that this status be granted the internal level through specified proceedings. The 2000 Friendship Treaty itself provides in its Article 15 that the equality status will only produce its effects as of the moment in which a decision granting such a status is issued and duly registered.$^{85}$ Consequently, in the absence of this formalisation, Brazilian

83 This situation is somewhat symmetrical to that assessed above on the extradition of nationals between Brazil and Portugal, which is mostly hindered by the Brazilian Constitution. In contrast, in this case, it is mostly the Portuguese Constitution that would hinder the non-extradition of each other's nationals to third States.

84 Supremo Tribunal Federal, PPE 302-QO, 16 November 1998, apud Ministério da Justiça - Secretaria Nacional de Justiça - Departamento de Estrangeiros, Manual de Extradição, Brasília, 2012, p. $45 \mathrm{f}$.

85 Although - at least in the case of Portugal - the decision itself may be issued ex officio (that is, not necessarily at the request of its potential beneficiary): see Article 26 (1) of Decree-Law no. 154/2003, of 15 July (see the following 
and Portuguese nationals will not benefit from such a protection against extradition to third States. An example of this is a case decided by the Brazilian Federal Supreme Court in 1996 - also still under the 1971 legal arrangement -, in which a Portuguese national who was not covered by the equality status was extradited to France, with the Court stressing the non-automaticity of this protection. ${ }^{86}$

\subsection{A comparative APPRAISAL}

Albeit similar at a first glance, the EU Law and the Brazil-Portugal limitations on extradition to third States are very different in many respects. Such differences reflect the fundamentally diverse nature of the bonds which bind the Member States of the EU and those which bind the two Atlantic countries, as well as the current characteristics of those two different clusters of States. In the impossibility to address all the differences between those two legal and political landscapes (and the many nuances within each of them), the following lines seek to outline those which appear to be the most prominent and interesting ones, with more emphasis being placed on conceptual than on practical issues.

a) The first difference that should be mentioned - and which ultimately, in a more or less direct manner, contributes to explaining all other differences - concerns the underlying reasons for those limitations on extradition to third States. In the EU, the concern is primarily with the effectiveness of the freedom of movement, which is one of the foundational elements of EU law and a pivotal aspect of this political and economic project. Even the non-discrimination element - albeit also a core element of EU Law - is somewhat secondary to the freedom of movement in the context of the development of the EU citizenship exception to extradition. This is why, although both elements are necessary to elicit this exception,

footnote). On the other hand, Article 21 of the 2000 Treaty provides for a duty on the two States to communicate to each other the individuals who obtain or loose the equality status.

86 Supremo Tribunal Federal, Extradição 674, 12 December 1996, apud Jeancezar Ditzz de Souza Ribeiro, "O Novo Estatuto de Igualdade entre Brasileiros e Portugueses”, Lex Humana 6 (2014), p. 108. 
the exception will not apply if the law of the Member State of origin does not provide for a nationality exception to begin with, because in this case free movement remains unharmed. ${ }^{87}$

In contrast, in the Brazilian-Portuguese relationship, limitations on extradition of each other's nationals seem to be less functionalised (or at least not as immediately functionalised) to purposes of political and economic integration. This should help to explain why the sheer movement of a Brazilian or of a Portuguese citizen onto the territory of the other State does not immediately spark any protection vis-à-vis third States, but is instead subordinated to certain substantial requirements notably, that the individual at issue be a permanent resident of the other State -, and even to a formal accreditation of such requirements through specific administrative proceedings.

b) The previous considerations lead to another issue. While the EU citizenship exception, as noted before, is an extrapolation of the classic nationality exception, the limitations on the extradition of Brazilian and Portuguese nationals to third States does not so directly follow from the citizenship status as such. Indeed, to the extent that they requires the individual to be a permanent resident of the State which accords protection vis-à-vis third States, those limitations do not constitute a pure long-armed nationality exception for Brazilians in Portugal and for Portuguese in Brazil. It is not citizenship, in its strictly abstract and symbolical dimensions, that is being given expression in Article 18 of the 2000 Friendship Treaty.

Rather, by requiring permanent residence, Article 18 presupposes the existence of meaningful connections between the State that accords protection and the individual in a more social than political sense - that is, as someone whose family, social and professional circles are based in that place. Thus, while EU citizens may now be protected from extradition to third States as of the very moment when they cross the border to another Member State, Brazilian or Portuguese citizens will not receive that type of protection in such immediate terms.

By the same token, if an EAW is requested to Portugal by a fellow Member State in respect of a Brazilian citizen who satisfies the conditions

87 See supra, § 3.1.1. 
of said Article 18, Portugal can always refuse or condition the execution of the warrant based on the rehabilitation exception contained in the FD-EAW, mentioned above.

c) Can Brazil and Portugal refuse to extradite each other's nationals to a third State with which they have in place an extradition treaty (legal instruments such as the EAW and the MAW included) based on which they would in principle be obliged to grant such a request? Norms such as those revealed by the ECJ in Petruhhin and those contained in the 2000 Friendship Treaty between Brazil and Portugal raise a classic problem of conflict of international obligations. This problem (which is similar to that which takes place between treaty-based obligations to extradite and treaty-based obligations to protect human rights) is too extensive and complex to be addressed here in a remotely satisfactory manner, but this potential for conflict should not be left unmentioned. ${ }^{88}$

Indeed, the Petruhhin principle generates situations of necessary breach of international obligations by the Member State: either it refuses extradition, thus complying with EU Law but breaching an extradition treaty with the third State, or the other way around. The same applies to the 2000 Friendship Treaty, which raises yet another issue, addressed below.

d) Whereas the EU citizenship exception, by definition, can only apply if, inter alia, the Member State to which extradition is requested could not extradite an own national, the 2000 Friendship Treaty contains an apparently self-standing rule which prohibits Brazil and Portugal from extraditing each other's citizens to third States in any circumstances, regardless of whether or not their own nationals could be extradited in the case at issue.

Nevertheless, an interpretation according to which the nationals of the other State could benefit from wider protection than even own nationals appears to lack teleological and historical grounding. It is quite doubtful that the drafters of the 2000 Friendship Treaty would have intended for such a radical approach. The basis for this contention is self-evident: underlying

88 See further on this topic in Harmen van der Wilt, "On the Hierarchy between Extradition and Human Rights”, in Erika De Wet / Jure Vidmar (eds.), Hierarchy in International Law: The Place of Human Rights, Oxford: Oxford University Press, 2012, p. 150 f.; and Miguel João Costa, Extradition Law... op. cit., Chap. 3, § 3.6. 
this protection vis-à-vis third States is an intention of Brazil and Portugal to promote equality between Portuguese and Brazilian citizens, whereas that interpretation would generate inequality (in terms similar to those which in the conceptual framework of EU Law are generally referred to as reverse discrimination).$^{89}$ From a historical perspective, it is indeed quite doubtful that the Portuguese State, which in the constitutional amendment of 1997 had made room for extraditing its own nationals in certain cases (notably regarding serious types of criminality such as terrorism), would have intended in 2000 to prevent itself from extraditing Brazilian citizens to third States in those very same cases. The provisions of the Brazilian and the Portuguese Constitutions which underpin the 'equality status' developed at the international level in 1971 and in 2000 are drafted by reference to the set of rights enjoyed by their own nationals. It simply does not make sense to - partly in the name of a citizenship status - surpass the set of rights that one assigns to one's own citizens.

Thus, it would appear that Article 18 of the Friendship Treaty between Brazil and Portugal will be best understood as providing that each other's nationals cannot be extradited (only) in cases where their own nationals could not be extradited either. Interpreted in this sense, the Friendship Treaty would produce similar effects as EU law insofar as this aspect is concerned. This view is also consistent from a systematic angle, in that the very same provision establishes that Brazilian and Portuguese nationals are subject to the criminal laws of the other State in the "same conditions as the respective nationals". That is, insofar as jurisdictional issues are concerned, it is Article 18 itself that reiterates the note of 'equality'.

e) The Friendship Treaty and EU Law do have one major common denominator, which precisely touches upon a jurisdictional issue: both are concerned with impunity, and, thus, neither admits that extradition be refused if the consequence would be impunity. ${ }^{90}$ As suggested before,

89 On the concept, see e.g. Koen Lenaerts, “'Civis Europaeus Sum': From the Cross-border Link to the Status of Citizen of the Union”, in Pascal Cardonnel / Allan Rosas / Pernilla Lindh (eds.), Constitutionalising the EU judicial system: Essays in honour of Pernilla Lindh, Oxford: Hart, 2012, p. $213 \mathrm{f}$.

90 Some authors have suggested that extradition of EU citizens should be refused regardless of a risk of impunity. Franz Leidenmühler / Sandra Grafeneder, 
this is a most reasonable approach. Sight should never be lost of the fact that, by refusing extradition based on a citizenship status (whether conferred by itself of by a partner-State), a State will be denying the State that deserves primacy at the jurisdictional level ( $s c$. the State in whose territory or against whose interests the offence was committed) the possibility to pass its own justice on the case, moreover with better prospects of reaching a fair decision. Jurisdiction and extradition are intertwined, in that they both pursue the same basic goal: to enable States to ascertain whether given individuals are criminally liable. This intrinsic relation is the essence of the old aut dedere aut judicare principle. Moreover, being cautious not to generate unwarranted punitive gaps is all the more justified where - as is the case here - refusal of extradition, although itself based on a treaty, may carry the breach of another treaty: the situation of necessary breach mentioned above. ${ }^{91}$

But even here there is an interesting difference between the Friendship Treaty and EU Law. In the case of EU Law, the possibility to prosecute the acts within the EU constitutes a condition for extradition to be refused to the third State: extradition can only be refused 'if' prosecution in the EU is possible. In Petruhhin, the ECJ by no means implied that Member States would have jurisdiction to prosecute the acts for which extradition is requested by third States. In fact, this only lends further strength to the view according to which this was not a development based strictly on EU citizenship, because States which provide for a

"Civis europaeus sum! - Current legal issues relating to the extradition of citizens of the Union to third States. Discussion of the Cases C-182/15, Petruhhin; C-473/15, Schotthöfer \& Steiner; C-191/16, Pisciotti”, European Legal Forum 3 (2016), p. 58 f. However, this position cannot be endorsed: not only for certain reasons more specific to EU Law, but also for the reasons expounded subsequently in the text, which in my view apply rather transversally in cooperation matters.

91 It is also interesting to note that both EU Law and the Friendship Treaty allow for prosecution to be carried out, not necessarily in the State to which extradition is requested by the third State, but in the State of which the person concerned is a national. That is, in both cases, the 'judicare' option - one of the alternatives for avoiding impunity - may itself involve a 'deditio' (that is, an extradition, or, in the case of the EU, an EAW) to the partner-State, on behalf of which extradition to the third State is refused. 
classic nationality exception (often in their constitutional law) ${ }^{92}$ do not make it dependent upon the condition that they are able to prosecute the acts (which they generally are, but based on a ground for jurisdiction established at the mere level of ordinary law). ${ }^{93}$

In contrast, Article 18 of the Friendship Treaty establishes - in fact, this is its opening provision - a basis for jurisdiction in criminal matters: "Portuguese and Brazilian citizens who are beneficiaries of the equality status are subject to the criminal law of the State in which they reside in the same conditions as the respective nationals". In this way, Brazil and Portugal will necessarily and assuredly have the prerogative to prosecute the offences committed by each other's nationals whose extradition they refuse pursuant to this Treaty. Thus, this refusal rests not dependent on anything. This is not only sensible in the light of the impunity issue, but also it is justified in the light of one aspect which has already been highlighted above in a different regard: the fact that those individuals are permanent residents of the State allows it to presume that they are acquainted with its penal law and reinforces their responsibility to comply with it. In this sense, this provision is not only (perhaps not even mainly) a manifestation of the aut dedere aut judicare principle - that is, a derivative basis for jurisdiction aimed at compensating for the nonextradition of those individuals -, but also a primary and self-standing basis for jurisdiction grounded on their substantial quality as residents.

f) A final note concerns the difference, within each of the normative frameworks in analysis, between the immediate (or direct) and the collateral (or indirect) effects of interstate affinity. In the EU, as we saw, being a national of a Member State has limited relevance as a ground for this State not to execute an EAW, while, since Petruhhin, being a national of a(ny) Member State may signify being protected against extradition to a third State. This brings the EU closer to criminal justice areas typical of a State, within which individuals can be almost unconditionally transferred to the adequate forum (be it a legal district

92 See Article 5 (LI) of the Brazilian Constitution, and Article 33 (3) of the Portuguese Constitution.

93 See Article 7 (II) (b) of the Brazilian Penal Code, and Article 5 (1) (e) of the Portuguese Penal Code. 
or, in the case of a federal State, a federated State), but to the exterior of which they benefit from certain protections which tend to apply somewhat homogeneously regardless of the forum where the decision whether or not to extradite is taken. This is consistent with the considerations adduced above on the EU as a highly cohesive political, legal and economic area.

In contrast, there is no such consistency in the case of BrazilPortugal relations. They refuse extradition of each other's nationals to third States - which is a most impressive signal of interstate affinity, for this is by no means standard practice or even relatively normal -, and yet they generally also refuse extradition of their own nationals to each other - even though extraditing own nationals is becoming increasingly normal. The dominant note is, in both directions, non-extradition. Of course, this has to do with the fact that the nationality exception is enshrined in their constitutions in general and abstract terms (with no differentiation as to the identity of the requesting State), and that from a political standpoint the nationality exception can be quite sensitive and difficult to amend. Even in the EU, without detriment to earlier measures, meaningful change in extradition matters arrived only with the EAW, and it took an event of extraordinary international impact (9/11) for Member States to reach the consensus necessary for adopting it. ${ }^{94}$

In the meantime, the road that can - and has - been followed by Brazil and Portugal is to devise trusted partners that justify intensified cooperation on their part, such that at the international level improvements continue to be pursued and the groundwork laid for changes at the national level to become operative if and when they are enacted.

\section{Conclusion}

In the field of cooperation in criminal matters, relations of interstate affinity produce two different and, in a sense, opposite trends insofar as concerns the nationality of the individual: they render

94 See e.g. Anne Weyembergh, "L'impact du 11 septembre sur l'équilibre sécurité / liberté dans l'espace pénal européen”, Emmanuelle Bribosia / Anne Weyembergh (eds.), Lutte contre le terrorism et droits fondamentaux, Bruxelles: Bruylant, 2002, p. 153 f. 
extradition easier between those States and more difficult from any of those States to third States. This is visible in the EU and in the bilateral relations between Brazil and Portugal, although these are two rather different types of interstate relations.

In the latter case, despite meaningful steps taken in that direction through the conclusion of international treaties which at least admit the extradition of own nationals (the first effect of interstate affinity mentioned above), cooperation remains hindered by the constitutional rules in force in those States. Nevertheless, the symbolism of those treaties should not be underestimated: they are illustrative of the close ties that bind those States together, and promising of further cooperation between them.

At present, there is hardly any sound argument (normative or empirical) in support of the old tradition of civil law States not to extradite their own nationals, at least when serious crimes are at stake. Nevertheless, inasmuch as the classic nationality exception preserves any validity or applicability, it is only natural that a State, in certain circumstances, will seek to provide identical treatment to the nationals of other States to which it is bound by strong ties of affinity.

For obvious reasons, such a protection should not be more intense than that which is provided to one's own nationals, and States should beware not to allow their policies of interstate friendship to generate impunity, notably where the third State is the one that was injured the most by the offence. The construction of EU law and the regime of the relations between Brazil and Portugal are satisfactory in this respect, since the requested individual can always either be prosecuted or extradited.

A comparative analysis of the limitations on extradition to third States from the EU and from Brazil or Portugal reveals important similarities, but several differences do exist which follow from the different nature of the underlying bonds, as well as from the current characteristics of those interstate relations. In the EU, the key to understanding limitations on extradition to third States lies in the freedom of movement, a cornerstone of an entire political and economic edifice. In contrast, in the relations between Brazil and Portugal, those limitations do not so visibly translate into advantages. Instead, they appear to be 
quite simply a consequence of a policy that pays tribute to a long-standing relationship of political affinity, built upon a time-honoured shared cultural heritage.

\section{References}

BAKER, Scott; PERRY, David; DOOBAY, Anand. A Review of the United Kingdom's Extradition Arrangements (Following Written Ministerial Statement by the Secretary of State for the Home Department of 8 September 2010) - Presented to the Home Secretary on 30 September 2011. 2011. Available at: in https://assets.publishing.service.gov.uk/government/uploads/system/uploads/attachment_data/file/117673/ extradition-review.pdf. Accessed 27 May 2019.

BLAKESLEY, Christopher L. The Law of International Extradition: A Comparative Study. In: DUGARD, John; VAN DEN WYNGAERT, Christine (eds.), International Criminal Law and Procedure. Brookfield: Dartmouth, 1996.

BLANCHET, Thérèse. From Workers to Citizens - The Evolution of European Citizenship, New Journal of European Criminal Law 7 (2016), https://doi. org/10.1177/203228441600700204

CAEIRO, Pedro. Fundamento, Conteúdo e Limites da Jurisdição Penal do Estado. O Caso Português. Coimbra: Wolters Kluwer Portugal | Coimbra Editora, 2010.

CAEIRO, Pedro. O procedimento de entrega previsto no Estatuto de Roma e a sua incorporação no direito português. In: O Tribunal Penal Internacional e a Ordem Jurídica Portuguesa. Coimbra: Coimbra Editora, 2004.

CAMEIRA, Maria Cecília de Sousa. A Arte do Compromisso: Tratado de extradição de criminosos entre Portugal e o Brasil (10.06.1872). In: CASTRO, Zília Osório de, et al. (eds.). Tratados do Atlântico Sul: Portugal-Brasil, 1825-2000. Lisboa: Ministério dos Negócios Estrangeiros, 2006.

CANOTILHO, J.J. Gomes; BRANDÃO, Nuno. A extradição de Portugal para o Brasil de cidadãos portugueses naturalizados, Revista Direito GV (forthcoming)

CASTRO, Zília Osório de. A 'Varanda da Europa' e o 'Cais do Lado de Lá' - Tratado de paz e aliança entre D. João VI e D. Pedro (29-08-1825). In: CASTRO, Zília Osório de, et al. (eds.). Tratados do Atlântico Sul: Portugal-Brasil, 1825-2000. Lisboa: Ministério dos Negócios Estrangeiros, 2006.

CORREIA, Eduardo. Direito Criminal (com a colaboração de Figueiredo Dias), Volume I. Coimbra: Almedina, 1963. 
COSTA, Miguel João. Extradition Law: Reviewing Grounds for Refusal from the Classic Paradigm to Mutual Recognition and Beyond. Leiden: Brill | Nijhoff, 2019 (forthcoming: https://brill.com/abstract/title/55916)

COSTA, Miguel João. The Emerging EU Extradition Law: Petruhhin and Beyond, New Journal of European Criminal Law 8 (2017). https://doi. org/10.1177/2032284417711576

COSTA, Miguel João. Dedere Aut Judicare? A Decisão de Extraditar ou Julgar à luz do Direito Português, Europeu e Internacional. Coimbra: Instituto Jurídico da Faculdade de Direito da Universidade de Coimbra, 2014. Available at: https://www.uc.pt/ fduc/ij/publicacoes/pdfs/tesesMD/tese-mestrado_1.pdf

CUNHA, Damião da. Artigo 33. ${ }^{\circ}$ In: MIRANDA, Jorge; MEDEIROS, Rui. Constituição da República Portuguesa Anotada: Vol. I, $2^{\text {nd }}$ ed.. Lisboa: Universidade Católica Editora, 2017.

DANTAS, Leila Poconé. Entrega de Nacionais ao Tribunal Penal Internacional versus Vedação Constitucional de Extradição, Revista da Escola Superior da Magistratura de Sergipe 10 (2007).

DEL'OLMO, Florisbal de Souza. Extradição de Nacional no Direito Brasileiro: O Pioneirismo do Caso Cláudia Hoerig, Revista da Faculdade de Direito Universidade Federal de Minas Gerais 69 (2016). https://doi.org/10.12818/P.0304-2340.2016v69p769

DEL'OLMO, Florisbal de Souza. A Extradição na Contemporaneidade: Breves Reflexões, Cadernos do Programa de Pós-Graduação da Universidade Federal do Rio Grande do Sul 4 (2005). https://doi.org/10.22456/2317-8558.50463

DELGADO, José de Pina; FONSECA, Jorge Carlos; DELGADO, Liriam Tiujo (org.). Aspectos Polémicos da Extradição em Cabo Verde e no espaço Lusófono: Nacionalidade, Pena Aplicável, Institutos Afins. Cidade da Praia: Editora do Instituto Superior de Ciências Jurídicas e Sociais, 2009.

DIAS, Jorge de Figueiredo. Direito Penal. Parte Geral. Tomo I: Questões Fundamentais. A Doutrina Geral do Crime. Coimbra: Coimbra Editora, 2004.

DINIZ, Irene Bogado; PEREIRA, Marcos Vinícius Torres. Uma Análise da Jurisprudência do Supremo Tribunal Federal sobre Extradição: O Brasil Não É o Paraíso para os Criminosos Estrangeiros, Cosmopolitan Law Journal 2 (2014). http:// dx.doi.org/10.12957/cosmopolitan.2014.12375

GOMES, Maurício Augusto. Aspectos da extradição no Direito brasileiro, Justitia 52 (1990). http://bdjur.stj.jus.br/dspace/handle/2011/24090 
HENZELIN, Marc. Le principe de l'universalité en droit pénal international: Droit et obligation pour les états de poursuivre et juger selon le principe de l'universalité. Basel: Schulthess Verlag, 2001.

JARDIM, José Vera. Por fim, podemos extraditar portugueses! - Explicações de um Ministro. In: NUNES, António José Avelãs, et al. A Inclusão do Outro. Coimbra: Coimbra Editora, 2002.

JÚNIOR, Luiz Carlos Ormay; ARRUDA, Rejane Alves de. O Processo de Extradição e seus Limites no Brasil: Apontamentos de Acordo com o Entendimento do Supremo Tribunal Federal, Revista Thesis Juris 7 (2018). https://doi.org/10.5585/ rtj.v7i2.559

KLIP, André. Europeans First!: Petruhhin, an Unexpected Revolution in Extradition Law, European Journal of Crime, Criminal Law and Criminal Justice 25 (2017). https://doi.org/10.1163/15718174-02503001

KLIP, André. European Criminal Law. An Integrative Approach, $3^{\text {rd }}$ ed. Cambridge: Intersentia, 2016.

LEIDENMÜHLER, Franz; GRAFENEDER, Sandra, "Civis europaeus sum! - Current legal issues relating to the extradition of citizens of the Union to third States. Discussion of the Cases C-182/15, Petruhhin; C-473/15, Schotthöfer \& Steiner; C-191/16, Pisciotti”. European Legal Forum 3 (2016).

LENAERTS, Koen. 'Civis Europaeus Sum': From the Cross-border Link to the Status of Citizen of the Union. In: CARDONNEL, Pascal; ROSAS, Allan; LINDH, Pernilla (eds.). Constitutionalising the EU judicial system: Essays in honour of Pernilla Lindh. Oxford: Hart, 2012.

LENZA, Pedro. Direito Constitucional Esquematizado, $20^{\text {th }}$ ed.. São Paulo: Saraiva, 2016.

LOPES, Guilherme Aresi Madruga. Extradição Passiva e Nacionalidade - Investigação sobre a viabilidade jurídica da extradição de pessoa que perdeu a nacionalidade brasileira originária, Bachelor Thesis - Universidade Federal do Rio Grande do Sul, Porto Alegre, 2018.

MARTINS, Fernando; FARIA, Pedro Leite de. Um Primeiro Passo no Bom Caminho O Tratado de Amizade e Consulta (16.11.1953). In: CASTRO, Zília Osório de, et al. (eds.). Tratados do Atlântico Sul: Portugal-Brasil, 1825-2000, Lisboa: Ministério dos Negócios Estrangeiros, 2006.

MATHISEN, Gjermund. Nordic Cooperation and the European Arrest Warrant: Intra-Nordic Extradition, the Nordic Arrest Warrant and Beyond, 
Nordic Journal of International Law 79 (2010). https://doi.org/10.1163/15718 1009X12581245929569

MATOS, Ricardo Jorge Bragança de. O princípio do reconhecimento mútuo e o Mandado de Detenção Europeu, Revista Portuguesa de Ciência Criminal 14 (2004).

MAZZUOLI, Valerio de Oliveira. Algumas Questões sobre a Extradição no Direito Brasileiro, Cadernos da Escola de Direito e Relações Internacionais 14 (2011).

MOORE, John Basset. A Treatise on Extradition and Interstate Rendition. Boston: Boston Book Company, 1891.

PEREIRA, Luís Silva. Contributo para uma Interpretação dos Artigos 12 n. 1 al. g) e $13 .^{\circ}$ al. c) da Lei n. ${ }^{\circ}$ 65/2003, de 23 de Agosto, Revista do Centro de Estudos Judiciários 7 (2007).

PIÇARRA, Nuno. A proibição constitucional de extraditar nacionais em face da União Europeia, Revista do Centro de Estudos Judiciários 7 (2007).

RIBEIRO, Jeancezar Ditzz de Souza. O Novo Estatuto de Igualdade entre Brasileiros e Portugueses, Lex Humana 6 (2014). http://dx.doi.org/10.14195/2175-0947_6-1_6

RITZ, Christian; VASCONCELOS, Bernardo. Extradition discrimination? Pisciotti's legal battle continues as Regional Court of Berlin refers questions of fundamental EU law principles to the CJEU, European Competition Law Review 37 (2016).

ROCHA, Manuel António Lopes; MARTINS, Teresa Alves. Cooperação Judiciária Internacional em Matéria Penal: Comentários. Lisboa: Aequitas / Editorial Notícias, 1992.

RODAS, João Grandino. Entrega de nacionais ao Tribunal Penal Internacional, Revista do Centro de Estudos Judiciários 4 (2000).

RODRIGUES, Anabela Miranda. O Direito Penal Europeu Emergente. Coimbra: Coimbra Editora, 2008.

RODRIGUES, Anabela Miranda. O Mandado de Detenção Europeu - Na Via da Construção de um Sistema Penal Europeu: Um Passo ou um Salto?, Revista Portuguesa de Ciência Criminal 13 (2003).

RÖHRIG, Markus. Nowhere to Hide? Extradition in Antitrust Cases from a European Perspective, Journal of European Competition Law \& Practice 6 (2015). https://doi.org/10.1093/jeclap/lpu099

SARMENTO, Cristina Montalvão. Tratado do Milénio: 500 Anos para Redescobrir a História (22.04.2000). In: CASTRO, Zília Osório de et al. (eds.), Tratados 
do Atlântico Sul: Portugal-Brasil, 1825-2000. Lisboa: Ministério dos Negócios Estrangeiros, 2006.

SATZGER, Helmut. Is mutual recognition a viable general path for cooperation?. In: Pedro Caeiro (org.), Proceedings of the Conference 'European Criminal Law in the Global Context: Values, Principles and Policies' (Abstracts). Coimbra: Instituto Jurídico da Faculdade de Direito da Universidade de Coimbra, 2018.

SATZGER, Helmut. International and European Criminal Law, München: Nomos Verlag, 2012.

SCHUTTE, Julian J. E. O Direito Internacional Público e a Competência Extraterritorial em Matéria Penal, Revista Portuguesa de Ciência Criminal 3 (1993).

SEGABINAZI, Fabiane. Uma análise da extradição no Direito brasileiro, Revista da Faculdade de Direito da Universidade Federal do Rio Grande do Sul 24 (2004). https://seer.ufrgs.br/revfacdir/article/view/73496/41379

SHEARER, Ivan Anthony. Non-Extradition of Nationals - A Review and Proposal, Adelaide Law Review 2 (1966).

SILVA, Germano Marques da. Direito Penal Português I, Parte Geral: Introdução e Teoria da Lei Penal. Lisboa: Editorial Verbo, 2001.

SOMERS, Margaret R. Genealogies of Citizenship: Markets, Statelessness, and the Right to Have Rights. Cambridge: University Press, 2008.

SOUZA, Artur de Brito Gueiros. Extradition in South America. The case of Brazil, ERA Forum 19 (2019). https://doi.org/10.1007/s12027-018-0536-1

STRANDBAKKEN, Asbjørn. Extradition between Nordic countries and the new Nordic Arrest Warrant. In: KEIJZER, Nico; VAN SLIEDREGT, Elies (eds.), The European Arrest Warrant in Practice. The Hague: T.M.C. Asser Press, 2009.

SUOMINEN, Annika. The Nordic Arrest Warrant finally in force, European Criminal Law Review 4 (2014). https://doi.org/10.5235/219174414811783379

SWART, Bert. Refusal of Extradition and the United Nations Model Treaty on Extradition, Netherlands Yearbook of International Law 23 (1992). https://doi. org/10.1017/S016767680000221X

VERVAELE, John. European Criminal Law and General Principles of Union Law, Research Papers in Law 5 (2005).

VESTERGAARD, Jørn; ADAMO, Silvia. Mutual Recognition in Criminal Matters: The Danish Experience, Scandinavian Studies in Law 54 (2009). 
WEYEMBERGH, Anne. L'impact du 11 septembre sur l'équilibre sécurité / liberté dans l'espace pénal européen. In: BRIBOSIA, Emmanuelle / WEYEMBERGH, Anne (eds.), Lutte contre le terrorism et droits fondamentaux. Bruxelles: Bruylant, 2002.

WILT, Harmen van der. On the Hierarchy between Extradition and Human Rights. In: WET, Erika De / VIDMAR, Jure (eds.), Hierarchy in International Law: The Place of Human Rights. Oxford: Oxford University Press, 2012.

\section{Informações adicionais e declarações dos autores (integridade científica)}

Declaração de conflito de interesses (conflict of interest declaration): o autor confirma que não há conflitos de interesse na realização das pesquisas expostas e na redação deste artigo.

Declaração de autoria e especificação das contribuições (declaration of authorship): todas e somente as pessoas que atendem os requisitos de autoria deste artigo estão listadas como autores; todos os coautores se responsabilizam integralmente por este trabalho em sua totalidade.

Declaração de ineditismo e originalidade (declaration of originality): o autor assegura que o texto aqui publicado não foi divulgado anteriormente em outro meio e que futura republicação somente se realizará com a indicação expressa da referência desta publicação original; também atesta que não há plágio de terceiros ou autoplágio. 
Dados do processo editorial

(http://www.ibraspp.com.br/revista/index.php/RBDPP/about/editorialPolicies)

- Recebido em: 07/04/2019

- Controle preliminar e verificação de plágio: 09/04/2019

- Avaliação 1: 10/05/2019

- Avaliação 2: 23/05/2019

- Decisão editorial preliminar: 23/05/2019

- Retorno rodada de correções: 27/05/2019

- Decisão editorial final: 06/06/2019
Equipe editorial envolvida

- Editor-chefe: 1 (VGV)

- Editor-associado: 1 (PC)

- Editor-assistente: 1 (CRG)

- Revisores: 2

\section{COMO CITAR ESTE ARTIGO:}

COSTA, Miguel João. Policies of International Friendship in Judicial

Cooperation in Criminal Matters: The Non-Extradition of Brazilian and Portuguese Nationals to Third States - A Comparison with EU Law. Revista

Brasileira de Direito Processual Penal, Porto Alegre, vol. 5, n. 2, p. 773-817, mai./ago. 2019. https://doi.org/10.22197/rbdpp.v5i2.241

\section{(c) $(1) \Theta$}

Esta obra está licenciada com uma Licença Creative Commons Atribuição-NãoComercial 4.0 Internacional. 